\title{
Inhibition of proteoglycan synthesis by transforming growth factor $\beta$ in anatomically intact articular cartilage of murine patellae
}

Peter $M$ van der Kraan, Elly L Vitters, Wim B van den Berg

\begin{abstract}
The effect of transforming growth factor $\beta$ (TGF $\beta$ ) on proteoglycan synthesis and degradation in anatomically intact articular cartilage of murine patellae was studied. Exogenously added TGF $\beta$ up to a concentration of $200 \mathrm{pmol} / \mathrm{l}$ had no effect on proteoglycan synthesis in intact articular cartilage. Neutralisation of endogenously produced TGF $\beta$ with a specific monoclonal antibody to TGF $\beta$, however, led to stimulation of proteoglycan synthesis, indicating that TGF $\beta$ itself inhibits proteoglycan synthesis in anatomically intact cartilage. Transforming growth factor $\beta$ decreased the degradation of proteoglycans in intact cartilage in the absence of fetal calf serum or insulin-like growth factor 1 . In the presence of fetal calf serum or insulin-like growth factor 1, TGF $\beta$ had no additional effect on proteoglycan breakdown.
\end{abstract}

Transforming growth factor $\beta$ (TGF $\beta$ ) is a multipotent regulator of cell growth and extracellular matrix synthesis. Five different subtypes of TGF $\beta$ are now known from cDNA libraries or by isolation from tissues or cells. Transforming growth factor $\beta$ is secreted as an inactive high molecular weight complex which has to be dissociated before functional activation of TGF $\beta$.

High levels of the active and latent forms of TGF $\beta$ are seen in synovial fluid from knee joints of patients with osteoarthritis and rheumatoid arthritis. ${ }^{12}$ Fava et al reported a concentration of $10 \cdot 1$ and $3.8 \mathrm{ng} / \mathrm{ml}$ active TGF $\beta$ in the synovial effusions of patients with rheumatoid arthritis and osteoarthritis, respectively. In a study by Miossec et al a mean synovial fluid concentration of $7 \cdot 2 \mathrm{ng} / \mathrm{ml}$ was found in the knee joint effusions of patients with rheumatoid arthritis. ${ }^{2} \mathrm{~A}$ four- to fivefold increase of active TGF $\beta$ levels was detected after treatment of synovial fluid with acid. ${ }^{12}$

The TGF $\beta$ concentrations present in synovial fluid of patients with rheumatoid disease might have profound effects on chondrocyte metabolism. Transforming growth factor $\beta$ has a biphasic effect on proteoglycan synthesis and cell proliferation of cultured growth plate chondrocytes from chicken and rabbits. ${ }^{3-6}$ Transforming growth factor $\beta$ increases proteoglycan and DNA synthesis dose dependently up to a concentration of $1 \mathrm{ng} / \mathrm{ml}$; higher concentrations have less stimulating effects. ${ }^{3-6}$ This biphasic effect of TGF $\beta$ on growth plate chondrocytes might be related to the presence of two types of TGF $\beta$ receptors on growth plate chondrocytes. ${ }^{6}$ Binding of TGF $\beta$ with the high affinity receptor results in stimulation of DNA synthesis whereas binding with the low affinity receptor leads to inhibition of DNA synthesis. ${ }^{6}$ On articular chondrocytes only inhibitory TGF $\beta$ receptors are seen. ${ }^{7}$

The effects of TGF $\beta$ on glycosaminoglycan synthesis of isolated articular cartilage chondrocytes are contradictory. Two groups reported an inhibitory effect of TGF $\beta$ on proteoglycan synthesis of articular cartilage chondrocytes ${ }^{78}$ whereas another group found a stimulating effect of TGF $\beta$ on articular chondrocyte glycosaminoglycan synthesis. ${ }^{9}$ Morales and Roberts reported stimulation of proteoglycan synthesis in bovine articular cartilage explant cultures by TGF $\beta$. There was a substantial lag time, however, in the response to $5 \mathrm{ng} / \mathrm{ml} \mathrm{TGF}$ $\beta$ and maximum stimulation of proteoglycan synthesis was observed only after a six day culture period. ${ }^{10}$

We studied the effects of TGF $\beta$ on proteoglycan synthesis and degradation in anatomically intact cartilage of murine patellae alone or in combination with fetal calf serum or insulin-like growth factor 1. Addition of TGF $\beta$ to the culture medium had no effect on the proteoglycan synthesis in anatomically intact cartilage. Depletion of endogenously produced TGF $\beta$ from the culture medium with monoclonal antibodies to TGF $\beta$, however, stimulated proteoglycan synthesis, indicating that TGF $\beta$ itself has inhibitory effects on proteoglycan synthesis in anatomically intact cartilage.

\section{Materials and methods} GROWTH FACTORS

Trifluoroacetic acid and acetonitrile were removed from transforming growth factor $\beta_{1}$ from human platelets (Calbiochem, La Jolla, CA, USA) with a vacuum concentrator (Savant Instruments, Farmingdale, NY, USA) and TGF $\beta$ was resuspended in $4 \mathrm{mM}$ hydrochloric acid with $0.1 \%$ bovine serum albumin (Sigma, St. Louis, MO, USA). Recombinant insulinlike growth factor 1 (Boehringer, Mannheim, Germany) was dissolved in $0.1 \mathrm{M}$ acetic acid (Merck, Darmstadt, Germany) with $0 \cdot 1 \%$ bovine serum albumin. All media (RPMI 1640 DM, Flow Laboratories, Irvine, UK) used in the experiments were supplemented with $0 \cdot 1 \%$ bovine serum albumin. 
old male C57B110 mice in good health weighing 20-25 g. Mice were killed by cervical dislocation and the whole patellae, with a standard amount of surrounding tissue, were dissected from the knee joints as described by van den Berg et al. ${ }^{11}$

EFFECT OF TGF $\beta$ ON PROTEOGLYCAN SYNTHESIS Anatomically intact patellae were incubated in RPMI 1640 DM medium (200 $\mu \mathrm{l} /$ patella) supplemented with pyruvate ( $1 \mathrm{mmol} / \mathrm{l}$, Merck) and glutamine $(2 \mathrm{mmol} / \mathrm{l}$, Merck $)$ at $37^{\circ} \mathrm{C}$ in a humidified $5 \%$ carbon dioxide atmosphere for 24 or 48 hours. At the start of the incubation period, TGF $\beta$ (0-5 ng/ml, 0-200 $\mathrm{pmol} / \mathrm{l})$ alone or in combination with $10 \%$ fetal calf serum (FCS, Flow Laboratories) or $0.5 \mu \mathrm{g} / \mathrm{ml}$ insulinlike growth factor 1 was added to the culture medium. An equivalent amount of $4 \mathrm{mM}$ hydrochloric acid or $0.1 \mathrm{M}$ acetic acid, or both, was added to the control cultures. An insulinlike growth factor 1 concentration of $0.5 \mu \mathrm{g} / \mathrm{ml}$ maintains proteoglycan synthesis on the in vivo level in murine patellae. ${ }^{12}$ In experiments with a 48 hour incubation period, the medium and growth factors were changed after 24 hours. During the last two hours of the incubation, 1.48 $\mathrm{MBq}$ sodium sulphate labelled with sulphur-35 (Du Pont de Nemours, Den Bosch, The Netherlands) was added to the culture medium.

Following incubation, the patellae were washed three times with physiological saline to remove non-incorporated sulphate labelled with ${ }^{35} \mathrm{~S}$ and subsequently fixed in ethanol (96\%). Decalcification of the patellae with $5 \%$ formic acid was followed by stripping of the articular cartilage layer. ${ }^{13}$ Patellar cartiliage was digested by lumasolve (Perstorp Analytical, OudBeyerland, The Netherlands) at $60^{\circ} \mathrm{C}$ and the amount of incorporated sulphate labelled with ${ }^{35} \mathrm{~S}$ was assayed by liquid scintillation analysis.

\section{EFFECT OF TGF $\beta$ ON PROTEOGLYCAN DEGRADATION}

Directly after isolation, patellae were incubated for three hours in medium with $1.48 \mathrm{MBq}$ sulphate labelled with ${ }^{35} \mathrm{~S}$ and subsequently washed three times with physiological saline. The amount of incorporated sulphate in the patellae $(n=6)$ directly after radiolabelling $(t=0)$ was assayed as described above. The remaining prelabelled patellae were incubated for 24 hours in medium containing various concentrations of TGF $\beta(0-5 \mathrm{ng} / \mathrm{ml}, 0-200 \mathrm{pmol} / \mathrm{l})$ alone or in combination with $10 \%$ fetal calf serum or $0.5 \mu \mathrm{g} / \mathrm{ml}$ insulin-like growth factor 1 . Following incubation, the patellae were processed as described above.

DEMONSTRATION OF ENDOGENOUS TGF $\beta$

The activity of TGF $\beta$ in culture supernatants of murine patellae was based on the inhibitory effect of TGF $\beta$ on the interleukin 1 induced production of interleukin 2 by NOB 1 cells. ${ }^{14}$ The NOB/interleukin 1 assay was carried out in microtitre plates (Costar, Cambridge, MA,
USA). To each well $10 \mu \mathrm{l}$ interleukin 1 (final concentration $10 \mathrm{U} / \mathrm{ml}$, Pfizer, Croton, NY, USA) and $5 \mu$ l culture supernatant were added. The culture supernatant was derived from a 24 hour culture of anatomically intact patellae (five patellae/ml). In addition, the wells were supplemented with either $25 \mu$ monoclonal antibody to TGF $\beta$ ( $1 \mathrm{mg} / \mathrm{ml}, 1 \mathrm{Dl1} .16), 25 \mu \mathrm{l}$ purified murine IgG ( $1 \mathrm{mg} / \mathrm{ml}$, Sigma), or $25 \mu$ physiological saline. The murine monoclonal antibody $1 \mathrm{D} 11.16$ has neutralising activity against TGF $\beta_{1}$ and TGF $\beta_{2} .{ }^{15}$ NOB 1 cells were washed twice with physiological saline and 100 $\mu \mathrm{l}$ NOB cells $\left(1 \times 10^{5}\right.$ cells/well $)$ was dispensed in the wells. Finally, $50 \mu$ l CTLL cells $\left(4 \times 10^{3}\right.$ cells/well) was added to the wells and the cluster dish was incubated for 20 hours at $37^{\circ} \mathrm{C}$ in a humidified $5 \%$ carbon dioxide atmosphere. The 20 hour incubation was followed by addition of $8.5 \mathrm{kBq} /$ well thymidine labelled with hydrogen-3 (Du Pont de Nemours) to the wells. After a further three hour incubation, the cells were harvested by an automatic cell harvester and the incorporated radioactivity determined by liquid scintillation counting.

The neutralising potential of the $1 D 11.16$ monoclonal antibody was estimated by studying the neutralising effect of $1 D 11.16$ on the inhibitory effects of known amounts of TGF $\beta_{1}$ in the NOB/interleukin 1 assay. The NOB/ interleukin 1 assay was carried out as described earlier. Instead of culture supernatant, however, known amounts of TGF $\beta_{1}(25 \mu \mathrm{l}, 0-50 \mathrm{ng} / \mathrm{ml})$ in combination with $25 \mu \mathrm{l}$ physiological saline or $1 \mathrm{D} 11.16(1 \mathrm{mg} / \mathrm{ml})$ were added to the wells.

\section{EFFECT OF MONOCLONAL ANTIBODY 1 D 11.16} ON PROTEOGLYCAN SYNTHESIS

Murine patellae were cultured for 24 or 48 hours in RPMI $1640 \mathrm{DM}$ medium $(200 \mu \mathrm{l} /$ patella) in the presence or absence of $0.5 \mu \mathrm{g} / \mathrm{ml}$ insulin-like growth factor 1 . At the start of the experiment, either $100 \mu \mathrm{g} 1 \mathrm{D} 11.16$ monoclonal antibody, $100 \mu \mathrm{g}$ purified mouse IgG, or physiological saline was added to cultures (final concentration $100 \mu \mathrm{g} / \mathrm{ml}$ ). During the 48 hour culture period the medium and supplements were changed after 24 hours. The last two hours of the incubation were performed in the presence of $0.74 \mathrm{MBq}$ labelled with ${ }^{35} \mathrm{~S}$ sulphate. After incubation, patellae were processed as described earlier.

\section{STATISTICS}

Statistical significance was tested by analysis of variance in combination with Student's $t$ test. A p value less than $5 \%$ was considered significant.

\section{Results}

Transforming growth factor $\beta$ has been reported to have pronounced effects on the proteoglycan synthesis of articular cartilage chondrocytes but we were unable to show any significant effects of exogenously added TGF $\beta$, up to a concentration of $200 \mathrm{pM}$, on proteoglycan 
synthesis in anatomically intact cartilage (fig 1). In contrast to insulin-like growth factor 1, TGF $\beta$ neither stimulated nor decreased proteoglycan synthesis, as measured by sulphate incorporation, in intact murine patellae after incubation periods of 24 and 48 hours. The presence of $10 \%$ fetal calf serum or $0.5 \mu \mathrm{g} / \mathrm{ml}$

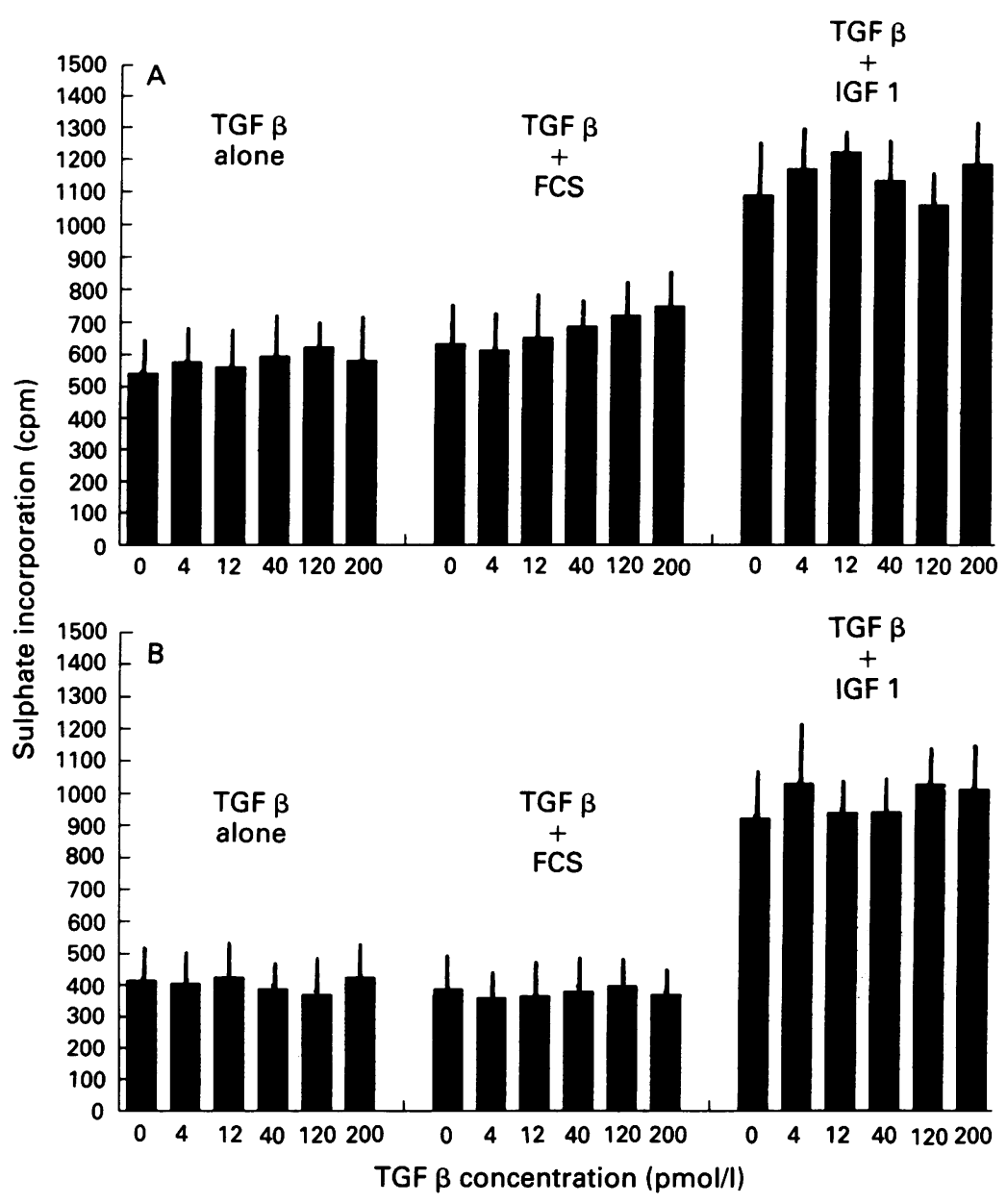

Figure 1 Effect of transforming growth factor $\beta(T G F \beta)$ on proteoglycan synthesis in anatomically intact cartilage. Murine patellae were incubated for 24 or 48 hours with TGF $\beta$ alone or in combination with fetal calf serum $(F C S)(10 \%)$ or insulin-like growth factor 1 $(I G F$ l) $(0.5 \mu \mathrm{g} / \mathrm{ml})$. For the last two hours of the incubation period sulphate labelled with sulphur-35 was added to the culture media to measure proteoglycan synthesis. Results are the mean $(S D)$ of five combined experiments. $(A) 24$ hours incubation; $(B) 48$ hours incubation.

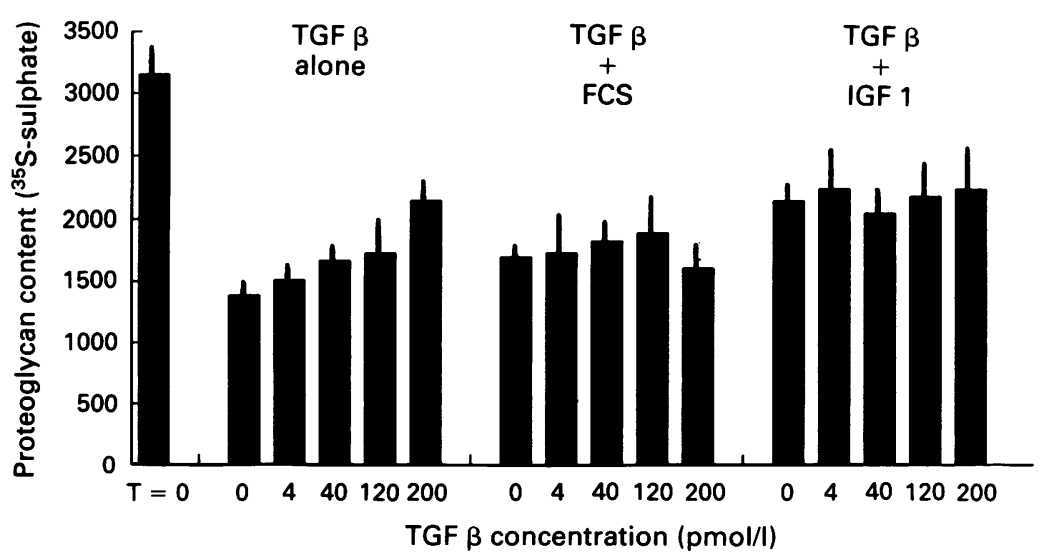

Figure 2 Effect of transforming growth factor $\beta(T G F \beta)$ on proteoglycan breakdown in anatomically intact cartilage. Sulphate labelled with sulphur-35 was added to the patellae and incubated for 24 hours in the presence of TGF $\beta$ alone or in combination with $10 \%$ fetal calf serum (FCS) or $0.5 \mu \mathrm{g} / \mathrm{ml}$ insulin-like growth factor 1 (IGF 1 ). The $t=0$ value is the amount of sulphate labelled with sulphur-35 incorporated directly after labelling. Results are the mean $(S D)$ of four combined experiments. insulin-like growth factor 1 had no modulatory influence on the effects of TGF $\beta$ on proteoglycan synthesis. As expected, insulin-like growth factor 1 stimulated the incorporation of sulphate into the murine articular cartilage.

One of our concerns was that the lack of effect of exogenously added TGF $\beta$ on proteoglycan synthesis was due to the fact that TGF $\beta$ did not reach the chondrocytes in the anatomically intact matrix. Exogenously added TGF $\beta$, however, had significant inhibitory, dose dependent, effects on ${ }^{35} \mathrm{~S}$ labelled proteoglycan degradation in anatomically intact cartilage. In the absence of fetal calf serum or insulin-like growth factor 1 , TGF $\beta$ concentrations of $40 \mathrm{pM}$ and higher significantly decreased the release of sulphated proteoglycans during a 24 hour culture period, measured by the reduction of ${ }^{35} \mathrm{~S}$ labelled sulphate in prelabelled patellae (fig 2). Fetal calf serum and insulin-like growth factor 1 significantly decreased the breakdown of proteoglycans in the absence of TGF $\beta$. Transforming growth factor $\beta$ had no additional effect on the fetal calf serum or insulin-like growth factor 1 induced reduction of proteoglycan degradation.

Another explanation of the absence of effect of exogenously added TGF $\beta$ on proteoglycan synthesis could be the presence of active endogenously produced TGF $\beta$ in the culture medium. Suggestive evidence was provided by the fact that the culture supernatant contained inhibitory activity when tested in the NOB/ interleukin 1 assay. Addition of the monoclonal antibody to TGF $\beta$ 1D11.16 totally circumvented the inhibitory effect of the culture supernatant whereas purified murine IgG had no neutralising effects (fig 3 ). These results show that the culture supernatant of anatomically intact patellae contains TGF $\beta$ activity and that this activity can be blocked by the neutralising antibody $1 \mathrm{D} 11.16$ in this murine system. The culture supernatant contained approximately 40 $\mathrm{pmol} / \mathrm{ml}$ active TGF $\beta$.

To test the neutralising potency of $1 \mathrm{D} 11.16$, the effect of $1 D 11.16$ on various known amounts of human TGF $\beta_{1}$ was tested in the NOB/interleukin 1 assay. 1D11.16 (100 mg) totally neutralised the effect of $0.5 \mathrm{ng}$ TGF $\beta_{1}$ in the NOB/interleukin 1 assay (fig 4). TGF $\beta_{1}$ (5 ng) was $47 \%$ neutralised by $100 \mu \mathrm{g}$ of the monoclonal antibody 1D11.16. Addition of 100 $\mu \mathrm{g} / \mathrm{ml} 1 \mathrm{D} 11.16$ to the patella cultures at the start of the experiment, to neutralise the endogenous TGF $\beta$ in the culture medium, significantly enhanced the incorporation of sulphate into the anatomically intact murine patellae in three of four different experiments (table). Monoclonal antibody to TGF $\beta$ stimulated proteoglycan synthesis in 24 hour patellae cultures in the presence of insulin-like growth factor 1 and in $\mathbf{4 8}$ hour cultures in the absence or presence of insulin-like growth factor 1 . Although the effects were only $10-15 \%$, significance was reached. This indicates that the endogenously produced TGF $\beta$ has an inhibitory effect on the proteoglycan synthesis of articular chondrocytes in anatomically intact cartilage. The addition of purified murine IgG had no effects on proteoglycan synthesis. 


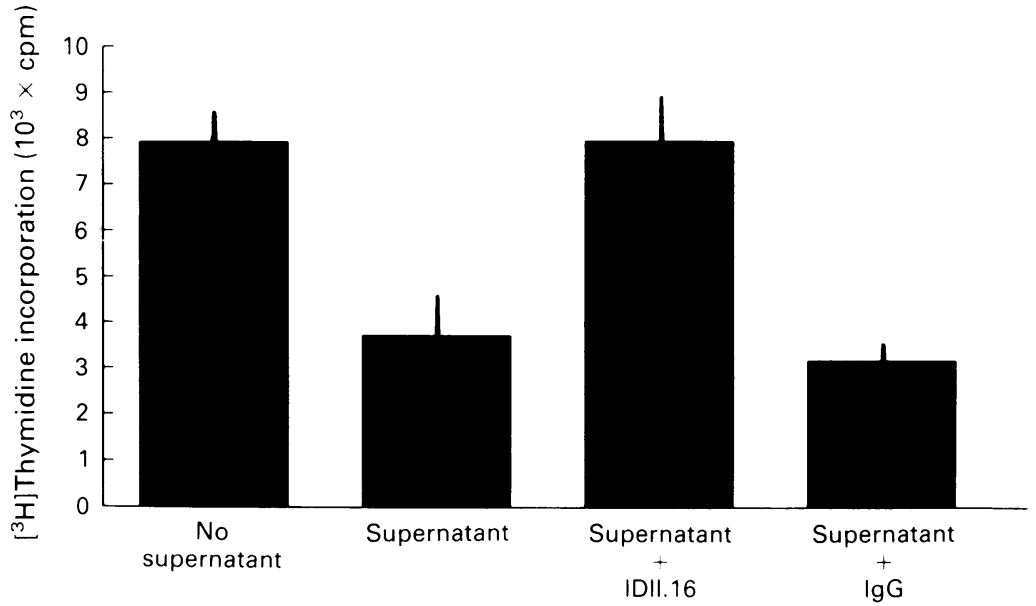

Figure 3 Inhibition of $\left[{ }^{3} \mathrm{H}\right]$ thymidine incorporation in the $\mathrm{NOB} /$ interleukin 1 assay by supernatant of patellae cultures. The NOB/interleukin 1 assay was performed in the presence of a standard amount of interleukin 1 . The supernatant of patella cultures alone or in combination with purified murine IgG or $1 D 11.16$ was added to the wells. Results are mean $(S D)$ of one representative experiment out of three.

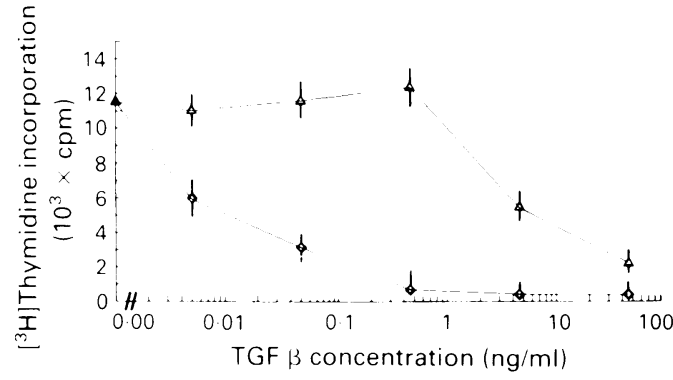

Figure 4 Neutralising effect of the monoclonal antibody to transforming growth factor $\beta(T G F \beta) 1 D 11.16$ in the $N O B /$ interleukin 1 assay. The NOB/interleukin assay was performed in the presence of a standard amount of $1 D 11.16(100 \mu \mathrm{g} / \mathrm{ml})$ and interleukin 1 and various amounts of human $T G F \beta 1$. Values are mean $(S D)$ of one representative experiment out of three. $(\diamond) T G F \beta$ $(\triangle) T G F \beta$ in combination with $1 D 11.16$.

\section{Discussion}

These data show that exogenously added TGF $\beta$ has no effect on proteoglycan synthesis in anatomically intact articular cartilage of murine patellae but that neutralisation of endogenous TGF $\beta$ leads to stimulation of proteoglycan synthesis. As a consequence of this TGF $\beta$ appears to inhibit proteoglycan synthesis in anatomically intact cartilage. These data support the observations of Skantze et al ${ }^{8}$ and Rosier et al. ${ }^{16}$ Skantze et al, using agarose cultures of rabbit articular chondrocytes, showed an inhibitory effect of TGF $\beta$ on chondrocyte glycosaminoglycan synthesis at a

Effect of antibodies to transforming growth factor $\beta(T G F \beta)$ on proteoglycan synthesis in anatomically intact murine patellar cartilage. Patellae were incubated for 24 or 48 hours in the presence or absence of insulin-like growth factor $1(0.5 \mathrm{ug} / \mathrm{ml})$. At the beginning of the experiment antibodies to TGF $\beta$, purified $\operatorname{Ig} G$, or saline were added to the culture media. The last two hours of the incubation took place in the presence of radiolabelled sulphate. The results given are the combined values (mean $(S D))$ of three experiments $(n=18)$

\begin{tabular}{|c|c|c|c|c|}
\hline & \multicolumn{4}{|c|}{ Incorporation of sulphate labelled with sulphur-35 (counts min) } \\
\hline & $\begin{array}{l}R P M I \\
(24 h)\end{array}$ & $\begin{array}{l}\text { Insulin-like } \\
\text { growth factor I } \\
(2+\mathrm{h})\end{array}$ & $\begin{array}{l}R I^{P} M I \\
(48 h)\end{array}$ & $\begin{array}{l}\text { Insulin-like } \\
\text { growth factor I } \\
(78 \mathrm{~h}\end{array}$ \\
\hline $\begin{array}{l}\text { Saline } \\
\text { Purified IgG } \\
\text { 1I)11.16 }\end{array}$ & $\begin{array}{l}512(101) \\
446(67) \\
481(71)\end{array}$ & $\begin{array}{l}824(116) \\
786(94) \\
898(97)\end{array}$ & $\begin{array}{l}340(66) \\
368(52) \\
+33(84)\end{array}$ & $\begin{array}{l}680(88) \\
694(88) \\
793(145)\end{array}$ \\
\hline
\end{tabular}

concentration of $0 \cdot 2 \mathrm{ng} / \mathrm{ml}(8 \mathrm{pmol} / \mathrm{l}){ }^{8}$ These results are confirmed by the observation of Rosier et al who found inhibitory effects of TGF $\beta$ on articular cartilage chondrocytes of chicken. ${ }^{16}$ Additionally, only inhibitory TGF $\beta$ receptors are seen on articular chondrocytes.

In contrast, Redini et al showed the stimulating effects of TGF $\beta$ on isolated rabbit articular chondrocytes. ${ }^{9}$ In our hands, TGF $\beta$ inhibited proteoglycan synthesis in freshly isolated bovine chondrocytes whereas it had a stimulating effect on proteoglycan synthesis in bovine chondrocytes cultured for seven days (data not shown).

Only one other study has been published on the effects of TGF $\beta$ on chondrocytes in a matrix. Morales and Roberts reported 20-60\% stimulation of proteoglycan synthesis after three days and maximum stimulation after six days in bovine articular explants by TGF $\beta .{ }^{10}$ This lag time in the response to TGF $\beta$ appears, however, to be absent in experiments with isolated chondrocytes. $^{7916}$ Inoue et al reported that TGF $\beta$ induces morphological dedifferentiation of chondrocytes and that these cells respond to TGF $\beta$ by stimulation of proteoglycan synthesis. ${ }^{17}$ Culturing of explants for several days in the presence of large amounts of TGF $\beta$ could lead to changes in the response of articular cartilage chondrocytes to TGF $\beta$.

The TGF $\beta$ activity present in the culture supernatants of patellae might be derived from the articular cartilage, the damaged surrounding tissues or both. Large amounts of TGF $\beta$ are present in articular cartilage ${ }^{18}$ and part of this might be released during cartilage culture in the active form. ${ }^{18}$ The fact that only small $(10-15 \%)$, although significant, stimulating effects of 1D11.16 on glycosaminoglycan synthesis were observed might be due to the fact that IgG antibodies are unable to penetrate intact articular cartilage. ${ }^{19}$ Decrease of active TGF $\beta$ from the articular cartilage matrix will be based on depletion of TGF $\beta$ from the culture medium, resulting in the increased release of TGF $\beta$ from the matrix to reach a state of equilibrium between TGF $\beta$ concentration inside and outside the matrix. Production of active TGF $\beta$ by the surrounding tissues will be neutralised by the 1D11.16 monoclonal antibody.

In contrast to the effect of TGF $\beta$ on synthesis, exogenously added TGF $\beta$ decreased the degradation of proteoglycans in anatomically intact cartilage, showing that TGF $\beta$ could reach the chondrocyte in the intact matrix. Transforming growth factor $\beta$ only had a significant effect in the absence of fetal calf serum or insulin-like growth factor 1. The presence of the TGF $\beta$ inhibitor $\alpha_{2}$ macroglobulin in fetal calf serum might be the reason for the absence of TGF $\beta$ effects on proteoglycan breakdown in the presence of fetal calf serum. ${ }^{20} 21$ Insulin-like growth factor 1 had a strong inhibitory effect on the degradation of proteoglycans in intact cartilage which might conceal the effects of TGF $\beta$ on proteoglycan breakdown. The differential effect of exogenously added TGF $\beta$ on proteoglycan synthesis or breakdown may be caused by 
differences in the TGF $\beta$ dose response relation of proteoglycan synthesis and degradation in anatomically intact cartilage. Neutralisation of endogenously produced TGF $\beta$ with monoclonal antibodies had no effect on proteoglycan breakdown, indicating that higher concentrations than those produced endogenously are needed to inhibit breakdown (data not shown).

This study indicates that TGF $\beta$ inhibits proteoglycan synthesis in normal chondrocytes in an anatomically intact matrix. However, in disease states such as osteoarthritis or rheumatoid arthritis chondrocytes might change phenotypically under the influence of cytokines and growth factors such as interleukin 1 and TGF $\beta .{ }^{17} 22$ Phenotypically changed chondrocytes might have a different expression of TGF $\beta$ cell membrane receptors from normal articular chondrocytes, rendering these cells susceptible to the matrix synthesis and cell proliferation promoting effects of TGF $\beta$, as seen with growth plate chondrocytes. In this way TGF $\beta$ could play a part in the regulation of matrix synthesis and cell proliferation (inhibition) in normal chondrocytes, as well as in the repair response of osteoarthritic cartilage, characterised by increased proteoglycan synthesis and chondrocyte proliferation.

The monoclonal antibody to TGF $\beta$ was kindly provided by Celtrix Laboratories, Collagen Corporation, Palo Alto, CA, USA. This study was supported by the Dutch League against rheumatism.

l Fava R, Olsen N, Keski-Oja J, Moses H, Pincus T. Active and latent forms of transforming growth factor $\beta$ activity in synovial effusions. $\mathcal{F}$ Exp Med 1989; 169: 291-6.

2 Miossec P, Naviliat M, Dupuy D'Angeac A, Sany J, Banchereau J. Low levels of interleukin-4 and high levels of transforming growth factor $\beta$ in rheumatoid synovitis. Arthritis Rheum 1990; 33: 1180-7.

3 Hiraki Y, Inoue H, Hirai R, Kato Y, Suzuki F. Effect of transforming growth factor $\beta$ on cell proliferation and glycosaminoglycan synthesis by rabbit growth-plate chondrocytes in culture. Biochim Biophys Acta 1988; 969: 91-9.

4 O'Keefe R J, Puzas J E, Brand J S, Rosier R N. Effects of transforming growth factor- $\beta$ on matrix synthesis by chick growth plate chondrocytes. Endocrinology 1988; 122: 2953-61.

5 O'Keefe R J, Puzas J E, Brand J S, Rosier R N. Effect of transforming growth factor- $\beta$ on DNA synthesis by growth plate chondrocytes: modulation by factors present in serum. Calcif Tissue Int 1988; 43: 352-8

6 Rosier R N, O'Keefe R J, Crabb I D, Puzas J E. Transforming growth factor beta: an autocriene regulator of chondrocytes. Connect Tissue Res 1989; 20: 295-301.

7 O'Keefe R J, Crabb I D, Puzas J E, Rosier R N. Differentia expression of transforming growth factor-beta receptors and biological effects in chondrocytes [abstract]. Trans Orthop Res Soc 1990; 15: 114

8 Skantze K A, Brinckerhoff C E, Collier J P. Use of agarose culture to measure the effect of transforming growth factor $\beta$ and epidermal growth factor on rabbit articular chondrocytes. Cancer Res 1985; 45: 4416-21.

9 Redini F, Galera F, Mauviel A, Loyau G, Pujol J P. Transforming growth factor $\beta$ stimulates collagen and glycosaminoglycan biosynthesis in cultured rabbit articular chondrocytes. FEBS Lett 1988; 234: 172-6.

10 Morales T I, Roberts A B. Transforming growth factor $\beta$ regulates the metabolism of proteoglycans in bovine

11 van den Berg W B, Kruysen M W M, van de Putte L B A The mouse patella assay. An easy method of quantitating articular cartilage chondrocyte function in vivo and in vitro. Rheumatol Int 1982; 1: 165-9.

12 Schalwijk J, Joosten L A B, van den Berg W B, van de Putte L B A. Chondrocyte nonresponsiveness to insulin-like growth factor 1 in experimental arthritis. Arthritis Rheum growth factor 1 in

13 De Vries B J, Vitters El, van den Berg W B, Schram D, van de Putte L B A. Determination of small quantities of sulfate $(0-12 \mathrm{nmol})$ in serum, urine, and cartilage of the mouse. Anal Biochem 1987; 163: 408-17.

14 Espevik T, Waage A, Faxvaag A, Shalaby M R. Regulation of interleukin-2 and interleukin-6 production from $T$-cells: involvement of interleukin-1 $\beta$ and transforming growth involvement of interleukin-1 $\beta$ and transfol

15 Dasch J R, Pace D R, Waegell W, Inenaga D, Ellingsworth L. Monoclonal antibodies recognizing transforming growth factor B. Bioactivity neutralization and transformin growth factor $\beta 2$ affinity purification. $\mathcal{F}$ I mmunol 1989; 142: 1536-41.

16 Rosier R N, O'Keefe R J, Crabb I D, Puzas J E, Brand J S Articular and growth plate chondrocytes exhibit markedly different metabolic responses to growth plate factors [abstract]. F Bone Miner Res 1988; S185: 468.

17 Inoue H, Kato Y, Iwamoto M, Hiraki Y, Sakuda M, Suzuki F. Stimulation of proteoglycan synthesis by morphological transformed chondrocytes grown in the presence of fibroblast growth factor and transforming growth factor-beta. blast growth factor and transformin
f Cell Physiol 1989; 138: 329-37.

18 Morales T I, Joyce M E, Sobel M E, Roberts A B. Autocrine production of TGF $\beta$ by calf articular cartilage [abstract]. Trans Orthop Res Soc 1990; 15: 109

19 Van Lent P LE M, van den Berg W B, Schalkwijk J, van de Putte L B A, van den Bersselaar L. The impact of protein size and charge on its retention in articular cartilage. Size and charge on its retention

20 Huang S, O'Grady P, Huang J. Human transforming growth factor-beta/alpha-2-macroglobulin complex is a latent form of transforming growth factor-beta. $\mathcal{F ~ B i o l ~ C h e m ~ 1 9 8 8 ; ~} 263$ 1535-41.

21 Danielpour D, Sporn M B. Differential inhibition of transforming growth factor $\beta 1$ and $\beta 2$ activity by $\alpha_{2}$-macroglobulin. F Biol Chem 1990; 265: 6973-7.

22 Goldring M B, Birkhead J, Sandell L J, Kimura T, Krane $S M$. Interleukin 1 suppresses expression of cartilagespecific types II and IX collagens and increases types I and III collagens in human chondrocytes. $\mathcal{f}$ Clin Invest 1988; 82: 2026-37. 